\title{
Acoustic and perceptual aspects of vocal function in children with adenotonsillar hypertrophy - effects of surgery
}

\author{
Inger Lundeborg Hammarström, Elisabeth Hultcrantz, \\ Elisabeth Ericsson and Anita McAllister
}

\section{Linköping University Post Print}

N.B.: When citing this work, cite the original article.

Original Publication:

Inger Lundeborg Hammarström, Elisabeth Hultcrantz, Elisabeth Ericsson and Anita McAllister, Acoustic and perceptual aspects of vocal function in children with adenotonsillar hypertrophy - effects of surgery, 2012, Journal of Voice, (26), 4, 480-487.

http://dx.doi.org/10.1016/j.jvoice.2010.11.003

Copyright: Elsevier

http://www.elsevier.com/

Postprint available at: Linköping University Electronic Press

http://urn.kb.se/resolve?urn=urn:nbn:se:liu:diva-61240 


\section{Acoustic and perceptual aspects of vocal function in children with adenotonsillar hypertrophy —effects of surgery}

Inger Lundeborg ${ }^{1}$, Elisabeth Hultcrantz ${ }^{2}$, Elisabeth Ericsson ${ }^{2,3}$ \& Anita McAllister ${ }^{1}$

Department of clinical and experimental medicine, ${ }^{1}$ Division of speech and language

pathology, ${ }^{2}$ Division of Oto-rhino-laryngology, Linköping University, Sweden, ${ }^{3}$ Department of Nursing Science, School of Health Sciences, Jönköping, Sweden

\section{Key words}

Voice quality; children; perceptual and acoustic analyses; tonsil surgery

Corresponding author: Inger Lundeborg, Department of clinical and experimental medicine, Division of speech and language pathology, Linköping University, S-501 85 Linköping, Sweden, Phone: +46101032511Fax +461032558, Email:inger.lundeborghammarstrom@liu.se 


\section{Abstract}

Objective: To evaluate outcome of two types of tonsil surgery (tonsillectomy+adenoidectomy or tonsillotomy +adenoidectomy) on vocal function perceptually and acoustically.

Study Design: Sixty-seven children, aged 50-65 months, on waiting list for tonsil surgery were randomized to tonsillectomy $(n=33)$ or tonsillotomy $(n=34)$. Fifty-seven age and gender matched healthy pre-school children were controls. Twenty-eight of them, aged 48-59 months, served as control group before surgery, and 29, aged 60-71 months, after surgery Methods: Before surgery and six months postoperatively, the children were recorded producing three sustained vowels (/A, v, $\mathrm{l} /$ ) and 14 words. The control groups were recorded only once.

Three trained speech and language pathologists performed the perceptual analysis using Visual Analogue Scales (VAS) for eight voice quality parameters. Acoustic analysis from sustained vowels included average fundamental frequency, jitter percent, shimmer percent, noise-to-harmonic ratio and the centre frequencies of formants 1-3

Results: Before surgery the children were rated to have more hyponasality and compressed/throaty voice $(\mathrm{p}<0,05)$ and lower mean pitch $(\mathrm{p}<0,01)$ in comparison to the control group. They also had higher perturbation measures and lower frequencies of the second and third formant. After surgery there were no differences perceptually. Perturbation measures decreased but were still higher compared to the control group's, $p<0,05$. Differences in formant frequencies for $/ \mathrm{l} /$ and $/ \mathrm{v} /$ remained. No differences were found between the two surgical methods.

Conclusion: Voice quality is affected perceptually and acoustically by adenotonsillar hypertrophy. After surgery the voice is perceptually normalized but acoustic differences remain. Outcome was equal for both surgical methods. 


\section{Introduction/background}

Most children between the ages of 3 to 5 years have a relative hypertrophy of the lymphoid tissue in the pharynx, including both the tonsils and the adenoid.(1-3) This enlargement can cause obstructive symptoms of varying degree (1-3) and several aspects of the speech spectrum such as resonance and articulation are reported to be negatively affected (4). Little work has been conducted on the effects of tonsillar hypertrophy and tonsillar surgery on voice and most studies have used perceptual evaluations. Since the characteristics of voice function are multidimensional, adequate assessments of voice must include both subjective and objective measures.(5) Regarding resonance, hypernasality as a result of enlarged tonsils hampering the velopharyngeal closure has been reported (6-9). Others state that hyponasal speech is common, especially when both the tonsils and the adenoid tissue are enlarged (10). Some characterize the impact on resonance by cul-de-sac resonance with a hollow and muffled sounding voice $(11,12)$. Titze and Story (13) have indicated that also supralaryngeal structures may impact the regulation of voice quality.

Tonsillar hypertrophy is treated with surgery usually tonsillectomy with or without adenoidectomy. This operation is one of the most frequently performed surgical procedures in children (14). During the last decade an alternative surgical technique, tonsillotomy, has been reintroduced $(15,16)$. In tonsillectomy (TE) a total extirpation of the tonsils is made, whereas only the obstructive tissue is removed in tonsillotomy (TT).

Although speech is very rarely reported among the indications for tonsil surgery (17), the treatment can potentially improve vocal quality by altering the resonance characteristics of the vocal tract. Several evaluations of changes in acoustic features following tonsillectomy with varying results have been published. Some report that preoperative normal speech becomes hypernasal after surgery (18), others a normalization of preoperative hypernasality $(11,19)$ 
using perceptual and acoustic measures.. There are also studies that indicate minimal impact on voice function after tonsillectomy (20) measured by fundamental and formant frequency changes. The question is how voice function is affected if only a partial resection of the tonsils, tonsillotomy is performed? Recent studies have shown that tonsillotomy has the same beneficial long-term effect on other obstructive symptoms such as sleep apnoea and snoring as tonsillectomy, while causing lower primary morbidity and less pain $(21,22)$. In a previous publication the present authors have shown that oral-motor function is equally improved after both tonsillectomy and tonsillotomy (23). The aim of the present study is to perceptually and acoustically evaluate vocal function in preschool children with hypertrophic adenotonsillar tissue in comparison to healthy children. The aim is also to compare surgical treatment outcome for two types of tonsil surgery (tonsillectomy+adenoidectomy or tonsillotomy +adenoidectomy). Post operative results will also be compared to a contol group of healthy age and gender matched children

\section{Material and methods}

The study was approved by the Medical Ethics Committee of Linköping University on 200311-04 (No 03-448) and on 2008-06-06 (No M138-08).

A total of 67 children aged 50 to 65 months, consisting of 28 girls and 39 boys on waiting list for tonsil surgery were included in the study. Thirty-three were randomized to tonsillectomy (TE) and 34 to tonsillotomy (TT). None of the participating children had had any voice therapy prior to the study. Fifty-seven healthy pre-school children, without snoring problems or known present or past history of adenotonsillar hypertrophy, aged 50 to 71 months from the same area were selected to make up two control groups. Twenty-eight children, aged 48 to 59 months, served as the control group before surgery, and 29 children aged 60 to 71 months, served as the control group after surgery, see Table 1. 
Table 1.

Number of boys and girls and mean age of participants and controls at the speech assessments before and after surgery

\begin{tabular}{cc|cc|cc}
\hline \multicolumn{2}{c|}{ Randomized for TE } & \multicolumn{2}{c|}{ Randomized for TT } & \multicolumn{2}{c}{ Controls } \\
\hline Preop & Postop & Preop & Postop & Younger & Older \\
$(\mathrm{n}=33)$ & $(\mathrm{n}=32)$ & $(\mathrm{n}=34)$ & $(\mathrm{n}=33)$ & $(\mathrm{n}=28)$ & $(\mathrm{n}=29)$ \\
$+11 \delta^{\lambda} 22$ & $+11 \diamond^{\lambda} 21$ & $+17 \diamond^{\lambda} 17$ & $+17 \delta^{\lambda} 16$ & $+13 \delta^{\lambda} 15$ & $+14 \overbrace{}^{\lambda} 15$ \\
$4 ; 10$ years & $5 ; 6$ years & $4 ; 9$ years & $5 ; 5$ years & $4 ; 9$ years & $5 ; 5$ years \\
\hline \hline
\end{tabular}

$\mathrm{TE}=$ Tonsillectomy $\mathrm{TT}=$ Tonsillotomy

At the pre-surgical assessment, all 67 children in the study group (mean age of 4 years, 9 months) and the 28 children in the younger control group participated (mean age of 4 years, 7 months). All operated children except one in each study-group (65) came to a follow-up visit after approximately six months (mean age 5 years, 5 months). A 'post operative' control group consisting of 29 children, mean age 5 years, 5 months, was also assessed.

\section{Surgery}

Thirty-three children were randomized for tonsillectomy, and 34 for tonsillotomy. Twentyfive of thirty-three children in the TE group and 28/34 children in the TT group were also planned for adenoidectomy during the same surgery session. Six children with otitis media with effusion (OME), three in each group were planned for grommet insertions as well.

\section{Assessments procedure}

Within a month before surgery, the children in the study groups, were recorded producing three sustained vowels (/A, $v, l /)$ and 14 words, elicited by picture naming. The recordings were made in the speech and language clinic in a sound treated room with sound absorbents on the walls and ceiling and also double doors. The criteria for the words chosen were that 
they should be well-known to most children and almost exclusively contain sonorants. The words were: blommor /flowers/, gungar/swings/, dörr/door/, halv /half/, ballonger /balloons/, banan /banana/, räv/fox/, lejon /lion/, näbb/beak/, rädd/afraid/, hår /hair/, öra /ear/, ögon /eyes/ nalle /teddy bear/ The speech samples were audio-recorded using a Marantz PMD 660 Professional Recorder and an Audiotechnica mb microphone at a distance of approximately $60 \mathrm{~cm}$ from the child's mouth. The children in the surgical groups were recorded again six months postoperatively. The younger and older control groups were recorded in a separate quiet room at their day care centres using the same equipment.

All children did not participate in all tasks and some recordings could not be used for the acoustical analyses due to background noise, see table 2 .

Table 2.

Number of children participating in the different tasks

\begin{tabular}{lcccc}
\hline & $\begin{array}{c}\text { Preop studygroup } \\
\mathrm{n}=67\end{array}$ & $\begin{array}{c}\text { Postop studygroup } \\
\mathrm{n}=65\end{array}$ & $\begin{array}{c}\text { Younger controls } \\
\mathrm{n}=28\end{array}$ & $\begin{array}{c}\text { Older controls } \\
\mathrm{n}=29\end{array}$ \\
\hline $\begin{array}{l}\text { Material for the } \\
\text { perceptual } \\
\text { evaluation }\end{array}$ & $\mathrm{n}=59$ & $\mathrm{n}=59$ & $\mathrm{n}=28$ & $\mathrm{n}=29$ \\
$\begin{array}{l}\text { Material for the } \\
\begin{array}{l}\text { acoustic } \\
\text { analysis }\end{array}\end{array}$ & $\mathrm{n}=42$ & $\mathrm{n}=48$ & $\mathrm{n}=20$ & $\mathrm{n}=26$ \\
\hline \hline
\end{tabular}

\section{Analysis}

The perceptual analysis

A perceptual analysis was made by three trained speech and language pathologists (SLP) independently and blinded with respect to surgical method and pre- or postoperative status. The analysis was performed on a predetermined form with visual analogue scales (VAS) previously used in a study of children's voice in relation to noise (24) and now expanded for the present investigation with voice quality parameters that potentially could be affected by 
tonsillar hypertrophy. The form included the following voice quality parameters: Hoarseness, breathiness, hyperfunction, roughness, hyponasality, hypernasality, compressed/throaty voice and pitch. The end-points of the VAS for all parameters except pitch were 'not at all' $(0 \mathrm{~mm})$ and 'a lot (100 mm). Pitch was represented by a 200-mm line with 'very low' and 'very high' marked, respectively, at the extremes and expected in the middle (Appendix 1).

\section{The acoustic analyses}

The acoustic analysis was made using the sustained vowels and the Praat software (http://www.fon.hum.uva.nl/praat/ Version 5.1.31, Paul Boersma and

David Weenink, Phonetic Sciences Department, University of Amsterdam). The following parameters were estimated: average fundamental frequency (f0), jitter percent, (local), shimmer percent (local), noise-to-harmonic ratio (NHR) and the centre frequencies of formant $1-3(\mathrm{~F} 1, \mathrm{~F} 2, \mathrm{~F} 3)$.

\section{Statistical analyses}

Demographic data were expressed with descriptive statistics. Group differences were analyzed using the Mann-Whitney $U$-test both for perceptual ratings and acoustic data. Interand intra rater agreement for perceptual ratings was calculated with Chronbach's alpha. Changes before and after surgery within the study groups were analyzed using the Wilcoxon signed-rank test.

$P$-values $<0.05$ were considered statistically significant. The statistical analyses were performed using SPSS $@$ Windows version 17.0. 


\section{Results}

The children received their surgery according to the randomization. No post-operative complications were reported. Adenoidectomy was performed in all planned cases.

\section{The perceptual evaluations}

\section{The ratings of the preoperative recordings}

The perceptual evaluations of the preoperative recordings demonstrated that the children in the study groups had higher mean ratings on VAS for the parameters hyponasality and compressed/throaty voice ( $\mathrm{p}<0,05)$, and also lower mean ratings of pitch $(\mathrm{p}<0,01)$, see table 3 and 5. When separating out the children who had tonsil surgery in combination with adenoidectomy and comparing them to the age-matched controls the result was the same but also higher ratings of hoarseness were found $(\mathrm{p}<0,03)$.

Scattered differences were also found between the study groups. They were that the children randomized to tonsillotomy (TT) were rated to have more breathy voices $(\mathrm{p}<0,05)$ and the children randomized to tonsillectomy (TE) were rated to have a higher pitch, $(\mathrm{p}<0,05)$. Compared to the age matched control group, the TE-group did not differ on any parameter but the TT-group had higher ratings on VAS for the parameters hyponasality and compressed/throathy voice $(\mathrm{p}<0,05)$. The control group had higher ratings of pitch than the TTgroup $(\mathrm{p}<0,01)$. 
Table 3.

Perceptual analysis with VAS of the parameters hoarseness, breathiness, hyperfunction, hyponasality, hypernasality, roughness and compresses/throaty for study groups and controls preoperatively expressed in average scores .

\begin{tabular}{|c|c|c|c|c|c|}
\hline & TE+TT & Control & $\begin{array}{c}\text { P- } \\
\text { value* }^{*}\end{array}$ & TE vs TT & $\begin{array}{c}\text { P- } \\
\text { value* }^{*}\end{array}$ \\
\hline Hoarseness ${ }^{\text {a) }}$ & $20.83 \pm 1.9$ & $18.45 \pm 2.8$ & ns & $19.33 \pm 2.7 / 22.2 \pm 2.9$ & ns \\
\hline Breathiness $^{\text {a) }}$ & $24.36 \pm 2.2$ & $22.59 \pm 3.1$ & ns & $19.75 \pm 2.8 / 28.82 \pm 3.2$ & 0.035 \\
\hline Hyperfunction $^{\text {a) }}$ & $14.86 \pm 1.2$ & $17.9 \pm 2.3$ & ns & $16.6 \pm 1.8 / 13.13 \pm 1.2$ & ns \\
\hline Roughness & $6.5 \pm 0.8$ & $5.7 \pm 0.9$ & ns & $6.9 \pm 1.3 / 6.15 \pm 0.9$ & ns \\
\hline Hyponasality & $5.06 \pm 0.7$ & $2.43 \pm 0.6$ & 0.011 & $3.91 \pm 0.6 / 6.17 \pm 1.6$ & ns \\
\hline Hypernasality ${ }^{\text {a) }}$ & $1.19 \pm 0.2$ & $1.24 \pm 0.3$ & ns & $1.13 \pm 0.2 / 1.26 \pm 0.2$ & ns \\
\hline Compressed/throaty ${ }^{\text {a) }}$ & $10.51 \pm 1.2$ & $7.31 \pm 1.4$ & 0.038 & $7.95 \pm 1.3 / 12.98 \pm 1.9$ & $\mathrm{~ns}$ \\
\hline
\end{tabular}

Table 5.

Perceptual analysis with VAS of pitch for study groups and controls pre- and postoperatively expressed in average scores.

\begin{tabular}{lccccc}
\hline & $\begin{array}{c}\text { TE+TT } \\
\mathbf{n}=\mathbf{6 7}\end{array}$ & $\begin{array}{c}\text { Control } \\
\mathbf{n = 5 7}\end{array}$ & $\begin{array}{c}\text { P- } \\
\text { value* }\end{array}$ & $\begin{array}{c}\text { TE vs TT } \\
\mathbf{n = 3 3 / n = 3 4}\end{array}$ & $\begin{array}{c}\text { P- } \\
\text { value* }\end{array}$ \\
\hline $\begin{array}{l}\text { Pitch } \\
\text { preoperatively }\end{array}$ & $99.2 \pm 1.0$ & $103.6 \pm 1.4$ & 0.009 & $101.74 \pm 1 / 96.74 \pm 1.5$ & 0.027 \\
$\begin{array}{l}\text { Pitch } \\
\text { postoperatively }\end{array}$ & $100.88 \pm 0.8$ & $104.48 \pm 1.6$ & $\mathrm{~ns}$ & $100.57 \pm 1.1 / 101.18 \pm 1.3$ & $\mathrm{~ns}$ \\
\hline \hline
\end{tabular}

VAS= Visual Analogue Scale $(0-200 \mathrm{~mm}), \mathrm{TE}=$ Tonsillectomy TT=Tonsillotomy

${ }^{\text {a) }}$ Mean $\pm \mathrm{SD}$, *Mann Whitney U-test

\section{The ratings of the postoperative recordings}

There were no significant differences between the perceptual ratings of the postoperative recordings for the two surgical groups and there were no significant differences between the children in the two study groups and the corresponding control group. There were significant 
changes after surgery within both study groups. The voices of children in the TE-group were rated to be less rough $(\mathrm{p}<0,05)$ and more breathy $(\mathrm{p}<0,01)$ after surgery. The voices of the children in the TT-group were rated to be less hyponasal. The voices of the TT-group also had less roughness, less compressed/throaty quality and higher pitch postoperatively, see table 6 .

\section{Table 4.}

Perceptual analysis with VAS of the parameters hoarseness, breathiness, hyperfunction, hyponasality, hypernasality, roughness, compresses/throaty and pitch for study groups preand post operatively expressed in average scores .

\begin{tabular}{|c|c|c|c|c|c|c|}
\hline & $\begin{array}{c}\text { TE preop/ } \\
\text { TE postop } \\
n=33\end{array}$ & $\begin{array}{c}\text { P- } \\
\text { value }^{*}\end{array}$ & $\begin{array}{c}\text { TTpreop/ } \\
\text { TT postop } \\
\text { n=34 }\end{array}$ & $\begin{array}{c}\text { P- } \\
\text { value* }\end{array}$ & $\begin{array}{c}\text { TE+TTpre/ } \\
\text { TE+TT post }\end{array}$ & $\begin{array}{c}\text { P- } \\
\text { value* }^{*}\end{array}$ \\
\hline Hoarseness & $\begin{array}{c}19.33 \pm 2.7 / \\
22 \pm 2.8\end{array}$ & ns & $\begin{array}{l}22.28 \pm 2.9 / \\
22.28 \pm 2.9\end{array}$ & ns & $\begin{array}{c}20.83 \pm 1.9 / \\
22.14 \pm 2\end{array}$ & ns \\
\hline Breathiness & $\begin{array}{l}19.75 \pm 2.8) / \\
28.14(3.3)\end{array}$ & 0.008 & $\begin{array}{l}28.82 \pm 3.2 / \\
28.61 \pm 3.3\end{array}$ & ns & $\begin{array}{l}24.36 \pm 2.2 / \\
28.38 \pm 2.3\end{array}$ & ns \\
\hline Hyperfunction & $\begin{array}{c}16.6 \pm 1.8) / \\
15.62 \pm 2\end{array}$ & ns & $\begin{array}{l}13.3 \pm 1.2 / \\
12.57 \pm 1.6\end{array}$ & ns & $\begin{array}{c}14.86 \pm 1.2 / \\
14.07 \pm 1.2\end{array}$ & ns \\
\hline Roughness & $\begin{array}{l}6.9 \pm 1.3) / \\
4.56 \pm 0.8\end{array}$ & 0.016 & $\begin{array}{c}6.15 \pm 0.9) / \\
4.21 \pm 0.9\end{array}$ & 0.002 & $\begin{array}{c}6.5 \pm 0.8 / \\
4.38 \pm 0.6\end{array}$ & 0.0001 \\
\hline Hyponasality & $\begin{array}{l}3.91 \pm 0.6 / \\
2.43 \pm 0.6\end{array}$ & ns & $\begin{array}{c}6.17 \pm 1.6) / \\
2.31 \pm 0.6\end{array}$ & 0.001 & $\begin{array}{l}5.06 \pm 0.7 / \\
2.37 \pm 0.6\end{array}$ & 0.0001 \\
\hline Hypernasality & $\begin{array}{l}1.13 \pm 0.2 / \\
1.67 \pm 0.4\end{array}$ & ns & $\begin{array}{c}1.26 \pm 0.2 / \\
1.2 \pm 0.2\end{array}$ & ns & $\begin{array}{l}1.19 \pm 0.2 / \\
1.43 \pm 0.2\end{array}$ & ns \\
\hline $\begin{array}{l}\text { Compressed } \\
\text { /throaty }\end{array}$ & $\begin{array}{l}7.95 \pm 1.3 / \\
6.64 \pm 1.3\end{array}$ & ns & $\begin{array}{c}12.98 \pm 1.9 / \\
7.45 \pm 1.4\end{array}$ & 0.002 & $\begin{array}{c}10.51 \pm 1.2 / \\
7.05 \pm 0.9\end{array}$ & 0.003 \\
\hline Pitch & $\begin{array}{c}101.74 \pm 1.5 / \\
100.57 \pm 1.1\end{array}$ & ns & $\begin{array}{l}96.74 \pm 1.5 / \\
101.18 \pm 1.3\end{array}$ & 0.003 & $\begin{array}{c}99.2 \pm 1 / \\
100.88 \pm 0.8\end{array}$ & 0.047 \\
\hline
\end{tabular}

Inter-rater agreement was 0,93 according to Cronbach's Alfa . A random selection of $10 \%$ of the recordings was copied and mixed with in the material in order to determine intra-rater agreement, also calculated with Cronbach's Alfa and found to be 0, 99, 0, 99 and 0, 93 for the three listeners respectively. 
Table 6.

Perceptual analysis with VAS of the parameters hoarseness, breathiness, hyperfunction, hyponasality, hypernasality, roughness and compresses/throaty for study groups and controls postoperatively expressed in average scores.

\begin{tabular}{lccccc}
\hline & TE+TT & Control & $\begin{array}{c}\text { P- } \\
\text { value* }\end{array}$ & TE vs TT & $\begin{array}{c}\text { P- } \\
\text { value* }^{*}\end{array}$ \\
\hline Hoarseness $^{\text {a) }}$ & $22.14 \pm 2.0$ & $20.44 \pm 2.6$ & ns & $22.00 \pm 2.8 / 22.28 \pm 2.9$ & ns \\
Breathiness $^{\text {a) }}$ & $28.38 \pm 2.3$ & $25.4 \pm 3.2$ & ns & $28.14 \pm 3.3 / 28.61 \pm 3.3$ & ns \\
Hyperfunction $^{\text {a) }}$ & $14.07 \pm 1.2$ & $15.9 \pm 1.7$ & ns & $15.62 \pm 2.0 / 2.57 \pm 1.6$ & ns \\
Roughness $^{\text {a) }}$ & $4.38 \pm 0.6$ & $3.78 \pm 0.6$ & ns & $4.56 \pm 0.8 / 4.21 \pm 0.9$ & $\mathrm{~ns}$ \\
Hyponasality $^{\text {a) }}$ & $2.37 \pm 0.6$ & $3.63 \pm 0.7$ & ns & $2.43 \pm 0.6 / 2.31 \pm 0.6$ & $\mathrm{~ns}$ \\
Hypernasality $^{\text {a) }}$ & $1.43 \pm 0.2$ & $1.8 \pm 0.4$ & $\mathrm{~ns}$ & $1.67 \pm 0.4 / 1.2 \pm 0.2$ & $\mathrm{~ns}$ \\
Compressed/throaty $^{\text {a) }}$ & $7.05 \pm 0.9$ & $7.2 \pm 1.3$ & $\mathrm{~ns}$ & $6.64 \pm 1.3 / 7.45 \pm 1.4$ & $\mathrm{~ns}$ \\
\hline
\end{tabular}

VAS= Visual Analogue Scale $(0-100 \mathrm{~mm}), \mathrm{TE}=$ Tonsillectomy TT=Tonsillotomy

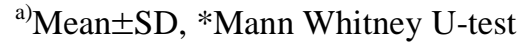

\section{The acoustic analysis}

\section{Preoperative results}

The acoustic analysis did not demonstrate any significant differences between the TE- and TT-group at the preoperative assessment. Compared to the control group, the children in the study-groups had higher values on jitter, shimmer and Noise to Harmonics Ratio (NHR) for all three vowels, se table 7 .

The study groups did not differ from the control group regarding fundamental frequency (f0) but had lower F3 values for and $/ \mathrm{v} /,(\mathrm{p}<0,01)$. For the vowel $/ \imath \mathrm{l}$, the study groups had significantly lower F2 and F3 values $(\mathrm{p}<0,01)$ than the younger control group, see figure 1. 
Table 7. Mean vocal parameters values: Jitter percent, shimmer and noise to harmonic ratio (NHR) for study groups and controls pre-operatively

\begin{tabular}{|c|c|c|c|c|c|c|c|c|c|}
\hline \multirow[b]{3}{*}{ Parameter } & \multicolumn{9}{|c|}{ vowel } \\
\hline & \multicolumn{3}{|c|}{$\mid \mathrm{A} /$} & \multicolumn{3}{|c|}{$/ \mathrm{v} /$} & \multicolumn{3}{|c|}{$/ \mathrm{l} /$} \\
\hline & $\mathrm{TE}+\mathrm{TT}$ & controls & $\begin{array}{c}\mathrm{P}- \\
\text { value* }\end{array}$ & $\mathrm{TE}+\mathrm{TT}$ & controls & $\begin{array}{c}\text { P- } \\
\text { value* }\end{array}$ & TE+TT & controls & $\begin{array}{c}\mathrm{P}- \\
\text { value* }\end{array}$ \\
\hline Jitter $^{\text {a) }}$ & $\begin{array}{c}1.11 \\
\pm 0.18\end{array}$ & $\begin{array}{c}0.57 \\
\pm 0.05\end{array}$ & $<0.05$ & $\begin{array}{c}1.14 \\
\pm 0.17\end{array}$ & $\begin{array}{c}0.65 \\
\pm 0.06\end{array}$ & $<0.05$ & $\begin{array}{c}1.39 \\
\pm 0.18\end{array}$ & $\begin{array}{l}0.72 \\
\pm 0.1\end{array}$ & $<0.05$ \\
\hline Shimmer ${ }^{\text {a) }}$ & $\begin{array}{l}13.52 \\
\pm 1.12\end{array}$ & $\begin{array}{c}7.95 \\
\pm 0.98\end{array}$ & $<0.01$ & $\begin{array}{l}14.10 \\
\pm 1.19\end{array}$ & $\begin{array}{c}6.39 \\
\pm 0.92\end{array}$ & $<0.001$ & $\begin{array}{l}13.88 \\
\pm 1.08\end{array}$ & $\begin{array}{c}6.04 \\
\pm 0.72\end{array}$ & $<0.001$ \\
\hline $\mathrm{NHR}^{\text {a) }}$ & $\begin{array}{c}0.14 \\
\pm 0.03\end{array}$ & $\begin{array}{c}0.05 \\
\pm 0.01\end{array}$ & $<0.001$ & $\begin{array}{c}0.11 \\
\pm 0.15\end{array}$ & $\begin{array}{c}0.02 \\
( \pm 0.01)\end{array}$ & $<0.001$ & $\begin{array}{c}0.13 \\
\pm 0.02\end{array}$ & $\begin{array}{c}0.03 \\
\pm 0.01\end{array}$ & $<0.001$ \\
\hline
\end{tabular}

TE= Tonsillectomy, TT=Tonsillotomy, ${ }^{a}$ Mean \pm SD, *Mann Whitney U-test

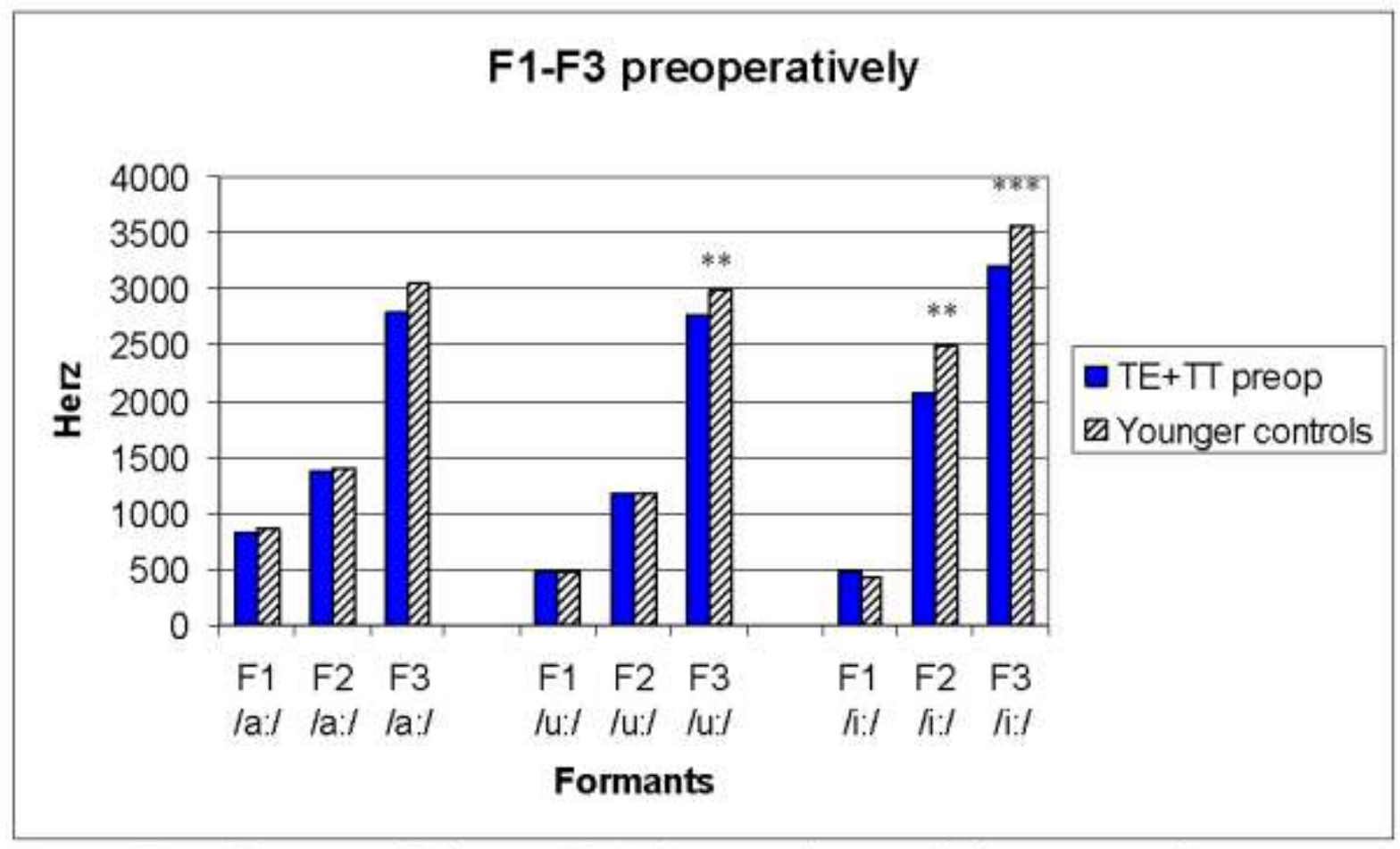

Figure 1. Centre frequencies for formant $1-3$ in the two study-groups before surgery and corresponding controls ( $\mathrm{TE}=$ tonsillectomy, $\mathrm{TT}=$ tonsillotomy) 


\section{Postoperative results}

The acoustic analyses showed a decrease in almost all measures of perturbation for the study groups after surgery with a slight difference between the two study groups. The children in the TT-group had higher shimmer value on the vowel $/ \mathrm{v} /(\mathrm{p}<0,05)$ and higher NHR for /A/ and $/ \mathrm{v} /(\mathrm{p}<0,05)$ compared to the children in the TE group, see table 8 . When comparing preversus postoperative results for the surgical group as a whole, there was a significant increase in formant 3 for the vowels /A/ and / $/$ at $\mathrm{p}<0,05$ postoperatively. No other differences were seen.

When separated according to surgical procedure the only observed difference was a higher F3 for $/ \mathrm{l} /$ in the TE group compared to the TT group, $\mathrm{p}<0,05$.

Table 8. Mean vocal parameters values: Jitter percent, shimmer and noise to harmonic ratio (NHR) for study groups postoperatively vowels

\begin{tabular}{|c|c|c|c|c|c|c|c|c|c|}
\hline \multirow[b]{2}{*}{ Parameter } & \multicolumn{3}{|c|}{ A } & \multicolumn{3}{|c|}{$v$} & \multicolumn{3}{|c|}{$l$} \\
\hline & $\mathrm{TE}$ & $\mathrm{TT}$ & $\begin{array}{c}\mathrm{P}- \\
\text { value }^{*}\end{array}$ & $\mathrm{TE}$ & $\mathrm{TT}$ & $\begin{array}{c}\mathrm{P}- \\
\text { value }\end{array}$ & $\mathrm{TE}$ & $\mathrm{TT}$ & $\begin{array}{c}\mathrm{P}- \\
\text { value }\end{array}$ \\
\hline Jitter $^{\text {a) }}$ & $\begin{array}{c}0.86 \\
\pm 0.14\end{array}$ & $\begin{array}{c}0.82 \\
\pm 0.11\end{array}$ & ns & $\begin{array}{c}1.0 \\
\pm 0.13\end{array}$ & $\begin{array}{c}1.25 \\
\pm 0.20\end{array}$ & $\mathrm{~ns}$ & $\begin{array}{c}1.12 \\
\pm 0.24\end{array}$ & $\begin{array}{c}1.53 \\
\pm 0.30\end{array}$ & $\mathrm{~ns}$ \\
\hline Shimmer ${ }^{\text {a) }}$ & $\begin{array}{l}1.29 \\
\pm 1.05\end{array}$ & $\begin{array}{c}14.16 \\
\pm 1.1\end{array}$ & ns & $\begin{array}{l}10.37 \\
\pm 1.16\end{array}$ & $\begin{array}{l}15.40 \\
\pm 1.49\end{array}$ & $<0.05$ & $\begin{array}{l}10.52 \\
\pm 1.32\end{array}$ & $\begin{array}{r}14.34 \\
\pm 1.44\end{array}$ & $\mathrm{~ns}$ \\
\hline NHR ${ }^{\text {a) }}$ & $\begin{array}{c}0.11 \\
\pm 0.02\end{array}$ & $\begin{array}{c}0.15 \\
\pm 0.02\end{array}$ & $<0.05$ & $\begin{array}{c}0.05 \\
\pm 0.01\end{array}$ & $\begin{array}{c}0.13 \\
\pm 0.02\end{array}$ & $\mathrm{~ns}$ & $\begin{array}{c}0.08 \\
\pm 0.02\end{array}$ & $\begin{array}{c}0.13 \\
\pm 0.02\end{array}$ & $\mathrm{~ns}$ \\
\hline
\end{tabular}

TE $=$ Tonsillectomy. TT $=$ Tonsillotomy, ${ }^{\text {a) }}$ Mean \pm SD,$*$ Mann Whitney U-test

When comparing the two study groups with the control group higher values were found for all perturbation measures for the study groups, see table 9 . 
Table 9. Mean vocal parameters values: Jitter. shimmer and noise to harmonic ratio (NHR) for study groups postoperatively compared to controls

vowels

\begin{tabular}{|c|c|c|c|c|c|c|c|c|c|}
\hline & \multicolumn{3}{|c|}{ A } & \multicolumn{3}{|c|}{$v$} & \multicolumn{3}{|c|}{$\mathrm{l}$} \\
\hline Parameter & $\mathrm{TE}+\mathrm{TT}$ & Controls & $\begin{array}{c}\mathrm{P}- \\
\text { value }^{*}\end{array}$ & $\mathrm{TE}+\mathrm{TT}$ & $\begin{array}{c}\text { Contro } \\
\text { ls } \\
\end{array}$ & $\begin{array}{c}\mathrm{P}- \\
\text { value }\end{array}$ & $\mathrm{TE}+\mathrm{TT}$ & Controls & $\begin{array}{c}\mathrm{P}- \\
\text { value }^{*}\end{array}$ \\
\hline Jitter $^{\text {a) }}$ & 0.84 & 0.55 & $<0.01$ & 1.14 & 0.51 & $<0.001$ & 1.33 & 0.53 & $<0.001$ \\
\hline Shimmer a) & 12.62 & 6.3 & $<0.001$ & 13.02 & 4.8 & $<0.001$ & 12.47 & 4.9 & $<0.001$ \\
\hline $\mathrm{NHR}^{\mathrm{a})}$ & 0.13 & 0.04 & $<0.001$ & 0.09 & 0.01 & $<0.001$ & 0.10 & 0.02 & 0.001 \\
\hline
\end{tabular}

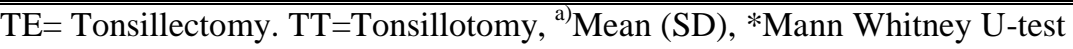

The analyses of centre frequencies in formant 1-3 of the /i/-sound showed significant differences in comparison to the older control group, $\mathrm{p}<0,01,0,01,0,05$ respectively. The difference regarding the lower third formant $(\mathrm{F} 3)$ of the $/ \mathrm{u} /$-sound remained $\mathrm{p}<0,05$, se figure 2.

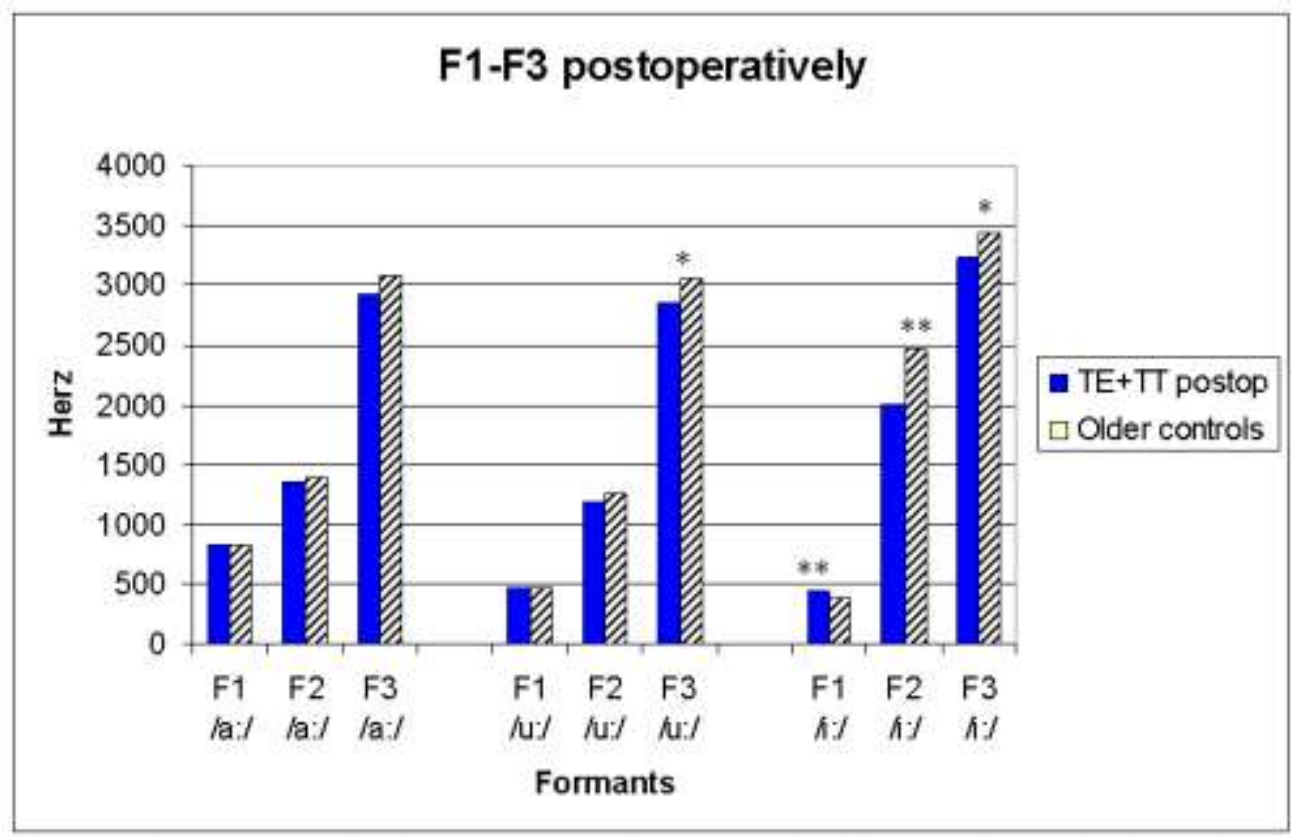

Figure 2. Fundamental frequency and centre frequencies for formant $1-3$ in the two studygroups after surgery and corresponding controls (TE=tonsillectomy, TT=tonsillotomy) 
There were no significant differences between the younger and the older control groups.

\section{Gender differences}

An overview of gender differences is summarized in table 10. In the study groups

preoperatively, boys were rated to have more breathy voices than girls, $\mathrm{p}<0,5$ and the girls were rated to have more high pitched voices, $\mathrm{p}<0,5$. The girls in the younger control group were rated to have breathier voices than the boys.

The only gender difference seen postoperatively was that the girls in the study groups were rated to have more high pitched voices than boys, $\mathrm{p}<0,001$.

Table 10. Significant gender differences in study group pre and postoperatively and in the younger and older controls

\begin{tabular}{|c|c|c|c|c|c|c|}
\hline & $\begin{array}{c}\text { O/ठ } \\
\text { TE+TT preop }\end{array}$ & P-value* & $\begin{array}{c}\text { O/ठ̄ं } \\
\text { Younger } \\
\text { controls }\end{array}$ & $\begin{array}{c}\mathrm{P}- \\
\text { value }\end{array}$ & $\begin{array}{c}\text { O/ठㄱ } \\
\text { TE+TT } \\
\text { postop }\end{array}$ & P-value ${ }^{*}$ \\
\hline Hoarseness ${ }^{\text {a) }}$ & $\begin{array}{c}24,71 \pm 2,8 / \\
15,69 \pm 2,4\end{array}$ & 0,05 & $\begin{array}{c}23,68 \pm 4,8 / \\
14,84 \pm 3,4\end{array}$ & 0,05 & 10 & ns \\
\hline Pitch $^{\text {a) }}$ & $\begin{array}{c}101,93 \pm 1,7 / \\
97,33 \pm 1,3\end{array}$ & 0,05 & -- & ns & $\begin{array}{c}106,03 \pm 1,3 / \\
97,36 \pm 1,0\end{array}$ & 0,001 \\
\hline $\operatorname{Shimmer}_{/ \mathrm{u} /}^{\text {a) }}$ & -- & $\mathrm{ns}$ & -- & ns & $\begin{array}{c}15,73 \pm 1,6 / \\
10,83 \pm 1,2\end{array}$ & 0,05 \\
\hline $\begin{array}{l}\mathrm{NHR}^{\mathrm{a})} \\
\quad / \mathrm{a} /\end{array}$ & -- & $\mathrm{ns}$ & -- & ns & $\begin{array}{c}0,16 \pm 0,02 / \\
0.11 \pm 0,02\end{array}$ & 0,05 \\
\hline $\begin{array}{l}\mathrm{NHR}^{\text {a) }} \\
/ \mathrm{u} /\end{array}$ & -- & ns & -- & ns & $\begin{array}{c}0,13 \pm 0,03 / \\
0,06 \pm 0,01\end{array}$ & 0,05 \\
\hline $\mathrm{NHR}^{\mathrm{a})}$ & -- & ns & -- & ns & $\begin{array}{c}0,14 \pm 0,03 / \\
0,07 \pm 0,02\end{array}$ & 0,05 \\
\hline
\end{tabular}

\begin{tabular}{|c|c|c|c|c|c|c|}
\hline $\begin{array}{l}\text { Formant } 1^{\mathrm{a})} \\
\mathrm{u} /\end{array}$ & $\begin{array}{c}520 \pm 17,2 / \\
446 \pm 18,3\end{array}$ & 0,05 & -- & ns & -- & $\mathrm{ns}$ \\
\hline Formant $2^{\text {a) }}$ & -- & $\mathrm{ns}$ & -- & ns & $\begin{array}{c}1477 \pm 50,7 / \\
1288 \pm 31,6\end{array}$ & 0,01 \\
\hline
\end{tabular}

$\mathrm{TE}=$ Tonsillectomy, $\mathrm{TT}=$ Tonsillotomy, ${ }^{\mathrm{a})}$ Mean Mean $\pm \mathrm{SD}, *$ Mann Whitney U-test 
No gender differences were seen regarding the perturbation measures, but a single difference in formant 1 frequency for the / $/$ sound was found with a higher frequency for girls in the study group. No gender differences were seen in the control group. Girl in the study groups had higher values of shimmer percent for the $/ \mathrm{v}$-sound, $\mathrm{p}<0,05$ and also higher NHR for all three vowels, $\mathrm{p}<0,05$. No gender differences were seen in the older control group, se table 10 see table 10 .

\section{Discussion}

The results of this study show that vocal function in children with tonsillar hypertrophy is affected with higher perturbation measures and lower frequencies of the third formant (F3) compared to healthy control children. The frequency of the third formant has been shown to be influenced by the tip of the tongue (25) In a previous study, oral motor function was investigated in the same children as in the present(23). A protruding positioning of the tip of the tongue was found more often in the children with tonsillar hypertrophy than in corresponding control group. Higher perturbation measures were expected since jitter and shimmer reflects the grade of hoarseness and roughness of the voice (19) and NHR is a general evaluation of the noise (26). Differences were also seen in the perceptual evaluations made by the experienced listeners, judging the voices of the children in the study groups to be significantly more hyponasal and with a more compressed/throathy and low-pitched voice than the control group. A hyponasal resonance is previously reported by several researchers to be associated with adenotonsillar hypertrophy $(10,27)$. The listeners in the present study did not rate presence of hypernasality in the study groups to a larger degree than in the control group. Although in other studies it has been suggested that hypertrophic tonsils contribute to hypernasality by preventing velopharyngeal closure (6-9). Nasality has been shown to be a 
parameter that is difficult to assess reliably (28). One explanation could be that there is a lack of agreement between raters about the definition of terms (29). Other influencing factors may be other co-existing speech variables or the degree of experience of rating nasality. In the present study the children in the study group had both deviant phonology and articulation (23, 30). The raters in the present study did not train together aiming at consensus regarding definitions of parameters' before the ratings. However both intra- and inter rater reliability were above 0,9 . The parameter compressed/throaty voice, that the raters perceived in a higher degree in the study-group children, could probably be attributed to the same perceptual phenomenon that others have described as "a muffled sounding voice" (12).

Given the higher perturbation measures in the study group one would expect that the listeners should give high ratings on the parameter roughness, as has been shown in a study by Bhuta and collegues (31). However, others have noted that listeners and acoustic analyses packages differ in measurement characteristics (32).

After surgery there were no difference between the ratings of the operated children and the control group, indicating a normalization of vocal function after the structural change. This is in line with the findings of Salami and colleagues (19) who also noted a postoperative normalization after adenotonsillectomy. Regarding the acoustic evaluations, there was a decrease in all perturbation measures after surgery. However these measures were all higher than those of the corresponding control group but did not seem to be significant for listeners. This indicates that the removal of the obstructive tissue (tonsillotomy) is sufficient for a perceptual normalization of vocal function. Also acoustically there were almost no differences between the two surgical groups, only a higher F3 in the TE-group for the /i/-sound .This could probably be attributed to increased space in the oropharyngeal area due to the complete removal of tissue. Tonsillotomy, which is associated with less postoperative pain and 
morbidity, could therefore be the recommended surgical method when treating tonsillar hypertrophy.

Scattered gender differences were found both in the study groups and in the control groups. Regarding breathiness boys in the study groups were rated to have more breathy voices than girls preoperatively and the girls were rated to have more high pitched voices. The higher prevalence of breathiness in the boys voices was surprising since this is a voice quality characteristic mostly found in girls (33). However the expected finding regarding breathiness occurred in the younger control group where girls were rated to have breathier voices than boys. The rated higher pitch in the girls remained also after surgery.

Regarding the acoustic measures the only consistent difference was for NHR where the girls in the study groups postoperatively had higher NHR for all three vowels. This corresponds to the expected higher prevalence of breathiness in girls and females.

The relatively low age and narrow age-span of the participants is probably the explanation of why it was difficult to get them all to complete all tasks. They had not met the person collecting the speech material earlier and the recordings were made in a non-familiar setting. When they came back for the post-operative assessment they were more familiar with the procedure and the milieu. Several of the recordings, especially those from the study groups' pre-operative assessment, could not be analyzed acoustically since the children's voice use deviated (for example in whispering or shouting).

\section{Conclusions}

Tonsillar hypertrophy affects vocal function according to both perceptual and acoustic analyses. After surgery vocal function and resonance is normalized independent of surgical procedure 


\section{Acknowledgments}

Many thanks to former SLP students (now graduated SLP's) Regina Agrassi and Kristin

Norén for all help with collecting the control material and initial compilation of all data.

\section{References}

1. Ahlqvist-Rastad J, Hultcrantz E, Svanholm H. Children with tonsillar obstruction: indications for and efficacy of tonsillectomy. Acta Paediatr Scand. 1988 Nov;77(6):831-5.

2. Lofstrand-Tidestrom B, Hultcrantz E. The development of snoring and sleep related breathing distress from 4 to 6 years in a cohort of Swedish children. Int J Pediatr Otorhinolaryngol. 2007 Jul;71(7):1025-33.

3. Lofstrand-Tidestrom B, Thilander B, Ahlqvist-Rastad J, Jakobsson O,

Hultcrantz E. Breathing obstruction in relation to craniofacial and dental arch morphology in 4-year-old children. Eur J Orthod. 1999 Aug;21(4):323-32.

4. Maryn Y, Van Lierde K, De Bodt M, Van Cauwenberge P. The effects of adenoidectomy and tonsillectomy on speech and nasal resonance. Folia Phoniatr Logop. 2004 May-Jun;56(3):182-91.

5. Oates J. Auditory-perceptual evaluation of disordered voice quality: pros, cons and future directions. Folia Phoniatr Logop. 2009;61(1):49-56.

6. Henningsson G, Isberg A. Influence of tonsils on velopharyngeal movements in children with craniofacial anomalies and hypernasality. Am J Orthod Dentofacial Orthop. 1988 Sep;94(3):253-61.

7. Subramaniam V, Kumar P. Impact of tonsillectomy with or without adenoidectomy on the acoustic parameters of the voice: a comparative study. Arch Otolaryngol Head Neck Surg. 2009 Oct;135(10):966-9.

8. Kummer AW, Billmire DA, Myer CM, 3rd. Hypertrophic tonsils: the effect on resonance and velopharyngeal closure. Plast Reconstr Surg. 1993 Apr;91(4):608-11.

9. Kummer AW, Myer CM, 3rd, Smith ME, Shott SR. Changes in nasal resonance secondary to adenotonsillectomy. Am J Otolaryngol. 1993 Jul-Aug;14(4):285-90.

10. Rahbar R. Adenotonsillar hypertrophy: The presentation and management of upper airway obstruction Seminars in Orthodontics 2004;10(4):244-6.

11. Shprintzen RJ, Sher AE, Croft CB. Hypernasal speech caused by tonsillar hypertrophy. Int J Pediatr Otorhinolaryngol. 1987 Nov;14(1):45-56.

12. Wetmore RF, Muntz HR, McGill TJ. Pediatric otolaryngology:principles and practics pathways. New York :: Thieme; 2000.

13. Titze IR, Story BH. Acoustic interactions of the voice source with the lower vocal tract. The Journal of the Acoustical Society of America. 1997;101(4):2234-43.

14. Younis RT, Lazar RH. History and current practice of tonsillectomy. Laryngoscope. 2002 Aug;112(8 Pt 2 Suppl 100):3-5.

15. Ericsson E, Lundeborg I, Hultcrantz E. Child behavior and quality of life before and after tonsillotomy versus tonsillectomy. Int J Pediatr Otorhinolaryngol. 2009 Sep;73(9):1254-62.

16. Koempel JA, Solares CA, Koltai PJ. The evolution of tonsil surgery and rethinking the surgical approach to obstructive sleep-disordered breathing in children. $\mathrm{J}$ Laryngol Otol. 2006 Dec;120(12):993-1000. 
17.

van den Akker EH, Schilder AG, Kemps YJ, van Balen FA, Hordijk GJ, Hoes AW. Current indications for (adeno)tonsillectomy in children: a survey in The Netherlands. Int J Pediatr Otorhinolaryngol. 2003 Jun;67(6):603-7.

18. Wachtel JM, Kuehn DP, Weiss KS. Hypernasality after tonsillectomy without adenoidectomy in an adult. Otolaryngol Head Neck Surg. 2000 Jan;122(1):112-3.

19. Salami A, Jankowska B, Dellepiane M, Crippa B, Mora R. The impact of tonsillectomy with or without adenoidectomy on speech and voice. Int J Pediatr Otorhinolaryngol. 2008 Sep;72(9):1377-84.

20. Chuma AV, Cacace AT, Rosen R, Feustel P, Koltaii PJ. Effects of tonsillectomy and/or adenoidectomy on vocal function: laryngeal, supralaryngeal and perceptual characteristics. Int J Pediatr Otorhinolaryngol. 1999 Jan 25;47(1):1-9.

21. Anand A, Vilela RJ, Guarisco JL. Intracapsular versus standard tonsillectomy: review of literature. J La State Med Soc. 2005 Sep-Oct;157(5):259-61.

22. Ericsson E, Graf J, Hultcrantz E. Pediatric tonsillotomy with radiofrequency technique: long-term follow-up. Laryngoscope. 2006 Oct;116(10):1851-7.

23. Lundeborg I, McAllister A, Graf J, Ericsson E, Hultcrantz E. Oral motor dysfunction in children with adenotonsillar hypertrophy-effects of surgery. Logoped Phoniatr Vocol. 2009 Jun 28:1-6.

24. McAllister AM, Granqvist S, Sjolander P, Sundberg J. Child voice and noise: a pilot study of noise in day cares and the effects on 10 children's voice quality according to perceptual evaluation. J Voice. 2009 Sep;23(5):587-93.

25. http://hyperphysics.phy-astr.gsu.edu/Hbase/music/vowel.html. Forming the vowel sounds, vocal, formants. [cited Access date 2010-06-30]; Available from.

26. Ilk HG, Erogul O, Satar B, Ozkaptan Y. Effects of tonsillectomy on speech spectrum. J Voice. 2002 Dec;16(4):580-6.

27. Paradise JL, Bernard BS, Colborn DK, Janosky JE. Assessment of adenoidal obstruction in children: clinical signs versus roentgenographic findings. Pediatrics. 1998 Jun;101(6):979-86.

28. Brunnegard K, Lohmander A, van Doorn J. Untrained listeners' ratings of speech disorders in a group with cleft palate: a comparison with speech and language pathologists' ratings. Int J Lang Commun Disord. 2009;44(5):656-74.

29. Sweeney T, Sell D. Relationship between perceptual ratings of nasality and nasometry in children/adolescents with cleft palate and/or velopharyngeal dysfunction. Int $\mathbf{J}$ Lang Commun Disord. 2008 May-Jun;43(3):265-82.

30. Lundeborg I, Ericsson E, Hultcrantz E, McAllister A. Influence of adenotonsillar hypertrophy on s-articulation in children - Effects of surgery. Submitted to Logopedics Phoniatrics Vocology. 2010.

31. Bhuta T, Patrick L, Garnett JD. Perceptual evaluation of voice quality and its correlation with acoustic measurements. J Voice. 2004 Sep;18(3):299-304.

32. Rabinov CR, Kreiman J, Gerratt BR, Bielamowicz S. Comparing reliability of perceptual ratings of roughness and acoustic measure of jitter. J Speech Hear Res. 1995 Feb;38(1):26-32.

33. McAllister A, Sederholm E, Sundberg J, Gramming P. Relations between voice range profiles and physiological and perceptual voice characteristics in ten-year-old children. J Voice. 1994 Sep;8(3):230-9. 
Appendix 1.

Perceptual evaluation of 4- and 5- year old children

Voice no:

Listener:

Not at all

A lot

Hoarseness

Breathiness

Hyperfunction

Rougness

Hyponasality

Hypernasality

Compressed/

Throaty

\section{Pitch}

Low

Expected

High

Comments: 